\title{
Leptospirosis in free-living capybaras (Hydrochaeris hydrochaeris) \\ from a university campus in the city of Araras in São Paulo, Brazil
}

\section{Leptospirose em capivaras de vida livre (Hydrochaeris hydrochaeris) de um campus universitário na cidade de Araras em São Paulo, Brasil}

\author{
Daniela Dib Gonçalves ${ }^{1 *}$; Karoline Franciane Cardoso Lopes ${ }^{2}$; Roberta Torres \\ Chiderolli³; Bruno Rodrigues Sampieriं; Vlamir José Rocha ${ }^{5}$; José Ricardo \\ Pachaly $^{6}$; Isabela Carvalho dos Santos ${ }^{2}$; Lidiane Nunes Barbosa ${ }^{1}$; Edinalva \\ Almeida Mota $^{2}$; Ulisses de Pádua Pereira ${ }^{7}$
}

\begin{abstract}
The capybara (Hydrochaeris hydrochaeris L. 1766) is the largest existing rodent in the world. This animal species, being synanthropic, may serve as a transmitter of different diseases and parasitic infections in animals and humans as well. Leptospirosis is a cosmopolitan infectious disease with a high prevalence in tropical and subtropical regions that can affect humans and other domestic and wild animals. Due to the absence of regional data and the importance of this animal species in transmitting diseases to animals and humans, the aim of this study was to analyze DNA and anti-Leptospira spp. antibodies in free-living capybaras (Hydrochaeris hydrochaeris) from a university campus in the city of Araras in São Paulo, Brazil. A total of 31 capybaras (Hydrochaeris hydrochaeris) were captured for collecting their blood samples. The collected sera were analyzed using the microscopic agglutination test (MAT). For the detection of Leptospira spp. DNA, the serum samples were used to extract genomic DNA for the nested-PCR analysis. Out of the 31 serum samples, $29(93.55 \%)$ were reactive for MAT, with titers ranging from 25 to 400 . The antibody could be identified against the most probable serovar in 26 (89.65\%) samples, namely: Grippotyphosa (69.23\%), Autumnalis (26.92\%), and Bratislava (3.85\%). Presence of Leptospira via nested-PCR was found only in $3.22 \%$ of serum samples. This study revealed the presence of DNA and anti-Leptospira spp. antibodies in free-living capybara. Characterization of these animals as possible carriers and disseminators of the etiological agent in the environment is necessary for identification of infection in other animals and campus visitors.
\end{abstract}

Key words: Antibodies. Grippotyphosa. Hydrichaeridae. Leptospira spp. Molecular Biology. Zoonosis.

\footnotetext{
1 Profs., Programa de Pós-Graduação em Ciência Animal com Ênfase em Produtos Bioativos, Universidade Paranaense, UNIPAR, Umuarama, PR, Brasil. E-mail: danieladibg@hotmail.com; linuba2@gmail.com

2 Discentes de Doutorado, Programa de Pós-Graduação em Ciência Animal com Ênfase em Produtos Bioativos, UNIPAR, Umuarama, PR, Brasil. E-mail: karol_lopes@hotmail.com; isabela_carvalhoxd@hotmail.com; edinalvamotarosa@gmail.com

3 Discente de Doutorado, Programa de Pós-Graduação em Ciência Animal da Universidade Estadual de Londrina, UEL, Londrina, PR, Brasil. E-mail: ro.vetuel@gmail.com

4 Discente de Doutorado, Universidade Estadual Paulista, UNESP, Rio Claro, SP, Brasil. E-mail: brunorsampieri@gmail.com

5 Prof., Universidade Federal de São Carlos, Araras, SP, Brasil. E-mail: vlamir@cca.ufscar.br

6 Médico Veterinário, Instituto Brasileiro de Especialidades Médicas Veterinárias, EspecialVet, Maringá, PR, Brasil. E-mail: pachaly@uol.br

7 Prof. Dr., Programa de Pós-Graduação em Ciência Animal, UEL, Londrina, PR, Brasil. E-mail: upaduapereira@gmail.com

* Author for correspondence
} 


\section{Resumo}

A capivara (Hydrochaeris hydrochaeris, L., 1766) é o maior roedor existente, pertencente a ordem Rodentia e família Hydrichaeridae. Esta espécie animal por ser sinantrópica pode ser transmissora de diferentes enfermidades infecto-parasitárias para animais e também para o homem. Entre as enfermidades, destaca-se a leptospirose, doença infecciosa cosmopolita com elevada prevalência em regiões tropicais e subtropicais que pode acometer o homem e outros animais domésticos e silvestres. Devido à ausência de dados regionais e a importância desta espécie animal para a saúde única o objetivo deste trabalho foi detectar DNA e anticorpos anti-Leptospira spp. em capivaras (Hydrochaeris hydrochaeris) de vida livre provenientes de um campus universitário da cidade de Araras em São Paulo, Brasil. Foram capturadas 31 capivaras (Hydrochaeris hydrochaeris), as quais passaram por coletas de sangue, onde os soros colhidos foram analisados mediante a técnica de Soroaglutinação Microscópica (SAM). Para a deteç̧ão de DNA de Leptospira spp., as amostras de soro foram submetidas a extração de DNA e esses submetidos à técnica de nested-PCR. Das 31 amostras de soro, 29 (93,55\%) foram reagentes na SAM com títulos variando de 25 a 400. Em 26 (89,65\%) amostras foi possível identificar o anticorpo contra o sorovar mais provável sendo: Grippotyphosa (69,23\%), Autumnalis $(26,92 \%)$ e Bratislava $(3,85 \%)$ e em uma amostra de soro $(3,22 \%)$ evidenciou-se a presença de leptospiras através da nestedPCR. Este estudo evidenciou a presença de DNA e anticorpos anti-Leptospira spp. em capivara de vida livre, caracterizando estes animais como possíveis portadores e disseminadores do agente etiológico no ambiente, permitindo a infecção de outros animais e também de visitantes do campus.

Palavras-chave: Anticorpos. Grippotyphosa. Hydrichaeridae. Leptospira spp. Biologia Molecular. Zoonose.

\section{Introduction}

The capybara (Hydrochaeris hydrochaeris L. 1766) is the largest existing rodent in the world. It belongs to the Rodentia order, in the Hydrichaeridae family. It has a daytime, semi-aquatic habit, and can be found practically everywhere in South America, except for the Andes regions (Rodrigues, 2013; Rodrigues et al., 2013; Pacheco et al., 2017). In Brazil, capybaras are broadly distributed, being one of the Brazilian wildlife species with the greatest potential for zootechnical exploitation (Antonucci, Souza, Ribeiro, Takemoto, \& Pavonea, 2012).

However, human activities such as deforestation for pasture, monocultures, and real estate developments and the resulting adaptation of the capybaras to civilized environments have become a public health concern. Because of the deforestation issue, the animals are now considered to comprise a synanthropic species, and thus, may host different infectious and parasitic diseases and transmit them to both animals and humans (Sinkoc, Brum, Muller, \& Brum, 2004; Santos, Zamora \& Ribeiro,
2011; Rodrigues et al., 2013; Carneiro, Miranda, Silveira, Linhares, \& Araújo, 2014; Chiacchio et al., 2014; Pacheco et al., 2017). Leptospirosis is a cosmopolitan infectious disease, which is highly prevalent in the tropical and subtropical regions and can affect humans and other domestic and wild animals (Faine, Adler, Bolin, \& Perolat, 1999; Oliveira, Arsky, \& Calda., 2013; Coelho, Chaves, Sá, Melo, \& Silva, 2014).

Leptospirosis can be transmitted through direct exposure to the urine of infected animals, or indirectly by exposure to water, food, and environments that have been contaminated with the urine of infected animals (Faine et al., 1999). Although capybaras are not considered one of the main reservoirs of leptospirosis, the animal species presents great potential for transmitting the disease, as it lives in areas with abundant water and mud. These environmental factors are essential for the survival of the etiological agent and consequently, the occurrence of the infection (Vasconcellos, Ito, \& Côrtes, 1987; Ito, Cacioppo \& Lang, 1998; Santos, 2017). 
In Brazil, more specifically in the states of São Paulo (SP) and Rio Grande do Sul (RS), studies for the detection of anti-Leptospira spp. antibodies in serum samples of free-living capybara and also those bred for human consumption record a prevalence of $60 \%, 27 \%$, and $26 \%$, respectively (Shimabukuro, 2006; Silva et al., 2009; Chiacchio et al., 2014), with different antibodies against the serovars. In 2010, in Iquitos in Peru, seropositivity of $86 \%$ was detected, with georgia, canicola, and ballum being the most frequent serovars (Cueva, Rivera, Sánchez, \& Ramírez, 2010).

Microscopic agglutination test (MAT) is most frequently used in the diagnosis of leptospirosis, and allows the evaluation of antibody titers against the different Leptospira spp. serovars. Different molecular techniques for detecting the DNA have also been used, which provide data regarding the final stage of infection (Faine et al., 1999). Due to the absence of regional data and the importance of this animal species with respect to human health, the aim of this study was to detect DNA and antiLeptospira spp. antibodies in free-living capybaras (Hydrochaeris hydrochaeris) from a university campus in the city of Araras in São Paulo, Brazil.

\section{Materials and Methods}

\section{Ethics committee}

This project was approved by the Authorization and Information System in Biodiversity (SISBIO) under protocol No. 37227-1 and by the Ethics Committee in Research involving Animal Experimentation (CEPEEA) at Universidade Paranaense (UNIPAR) under protocol No. 26226/2014.

\section{Study area}

The study site belongs to an area located in the city of Araras in the state of São Paulo, Brazil, with a total area of 226 hectares, with a fragment of 12.7 hectares of seasonal semi-deciduous forest and two lakes. This area contains an estimated capybara population of approximately 56 individuals, with no contact to other animals on campus.

\section{Capture of animals}

The animals were captured between July 2013 and March 2014, when the bait was placed, and they were contained in pens made of galvanized wire mesh measuring $4 \times 3 \mathrm{~m}$, equipped with guillotinetype doors. Corn, banana three leaves, and mineral salt were used as bait to attract the animals to the trap, and a period of four months was set for adaptation. During this period, the doors were kept open for the animals to get used to the location. After this period, the capybaras were captured directly inside the trap and physically contained using nets. Their eyes were covered with fabric towels to reduce the stress; in this manner, the animals could be handled well and their blood could be withdrawn (Pacheco et al., 2017).

\section{Identification of animals}

The animals were identified for genders, marked with numbered earrings of carbon steel applied in outside of the right ear, and then released in the same place after the collection of blood.

\section{Sample collection}

A sample of approximately $10 \mathrm{~mL}$ of blood was collected from each animal by a puncture to a cephalic or jugular vein, using individual disposable needles and syringes. The blood was placed in a test tube and kept at room temperature until coagulation retraction. The serum obtained from each sample was then stored in a sterile flask, duly identified and stored at $-20^{\circ} \mathrm{C}$ at the Laboratory of Preventive Veterinary Medicine in the Post-graduation Program in Animal Sciences at Universidade Paranaense (UNIPAR) for posterior serological and molecular 
diagnosis at the Laboratory of Leptospirosis in the Department of Preventive Veterinary Medicine (DMVP) at the State University of Londrina (UEL).

\section{Serological diagnosis}

For the detection of anti-Leptospira spp. antibodies, the sera were submitted to MAT with live antigens (Faine et al., 1999). A total of 20 reference serovars were used: Australis, Bratislava, Autumnalis, Butembo, Castellonis, Bataviae, Canicola, Cynopteri, Grippotyphosa, Hebdomadis, Copenhageni, Icterohaemorrhagiae, Panama, Pomona, Pyrogenes, Hardjo, Wolffi, Shermani, Sentot, and Tarassovi. The antigens were kept at 28 ${ }^{\circ} \mathrm{C}$ for 5 to 10 days in Difco ${ }^{\mathrm{TM}}$ Leptospira Enrichment (DIFCO ${ }^{\circ}$ - Sparks, MD - USA) medium modified by the addition of rabbit serum (Gonçalves et al., 2006). A dilution of 1:100 was used as a cutting point (Myers, 1985).

Sera presenting at least $50 \%$ agglutinated leptospira were considered as reagents, and the reagent samples were geometrically diluted in a ratio of two until reached the maximum positive dilution. The analysis of the results was considered the serovar presenting the highest title as being the most probable one (Vasconcellos et al., 1997) and the sera presenting co-agglutination in the highest dilution were considered reagent only to Leptospira spp. (Almeida, Martins, Brod, \& Germano, 1994).

\section{Molecular diagnosis}

To detect the Leptospira spp. DNA, all serum samples were subjected to DNA extraction using the PureLink Genomic DNA Mini Kit
(Invitrogen - Carlsbad, CA - USA) extraction kit. Later, the DNAs were used for the nested-PCR approach (n-PCR) using the following primers: A, 5'-GGCGGCGCGTCTITAAACATG-3'; B, 5'-TTCCCCCCATTGAGCAAGATT-3'; C, 5'-CAAGTCAAGCGGAGTAGCAA-3'; and D, 5'-CTTAACCTGCTGCCTCCCGTA-3' as previously described by Merien, Amouriaux, Perolat, Baranton and Saint Girons (1992) for 16S gene amplification at the bacterial genus level. The PCR reactions were performed using the Platinum PCR SuperMix Kit (Invitrogen - USA) according to the manufacturer instructions, as set forth below: each reaction contained $45 \mu \mathrm{L}$ of SuperMix, $1 \mu \mathrm{L}$ each primer $(10 \mathrm{nM})$, and $3 \mu \mathrm{L}$ DNA from the serum samples. Negative control (ultra-pure water) and positive control (strain Canicola) were also used in the reaction.

The final product from the n-PCR amplification was separated by $2 \%$ agarose gel electrophoresis containing ethidium bromide $(0.05 \mu \mathrm{g} / \mu \mathrm{L})$, and visualization of DNA was performed in an ultraviolet transilluminator. The positive sample was identified with a $331 \mathrm{bp}$ PCR product.

\section{Results}

From the 31 capybaras captured, 29 (93.55\%) were females and two $(6.45 \%)$ were males. Out of 31 serum samples, 29 (93.55\%) were reactive for MAT, with titers ranging from 25 to 400 . It was possible to identify the antibody against the most probable serovar in $26(89.65 \%)$ serum samples: Grippotyphosa (69.23\%), Autumnalis (26.92\%) and Bratislava (3.85\%) (Table 1). 
Table 1

Most probable serovars and titers detected in the microscopic agglutination test for leptospirosis in 26 serovar reagent samples from free-living capybaras (Hydrochaeris hydrochaeris) from a university campus in the city of Araras in São Paulo, Brazil, 2013-2014

\begin{tabular}{lllllllll}
\hline \multirow{2}{*}{ Most Probable Serovars } & \multicolumn{3}{l}{ Antibody Titers } & & & \multirow{2}{*}{ Total } & $(\%)$ \\
\cline { 2 - 6 } & 25 & 50 & 05 & 200 & 400 & 09 & 18 & 69,23 \\
Grippotyphosa & 01 & 00 & 05 & 01 & 01 & 02 & 07 & 26,92 \\
Autumnalis & 01 & 02 & 01 & 00 & 00 & 01 & 3,85 \\
Bratislava & 00 & 00 & 02 & 07 & 04 & 11 & 26 & 100 \\
\hline Total & 02 & 02 &
\end{tabular}

DNA of Leptospira spp. was detected in one serum sample (3.22\%) through the n-PCR analysis, which generated a $331 \mathrm{bp}$ PCR product (Figure 1).

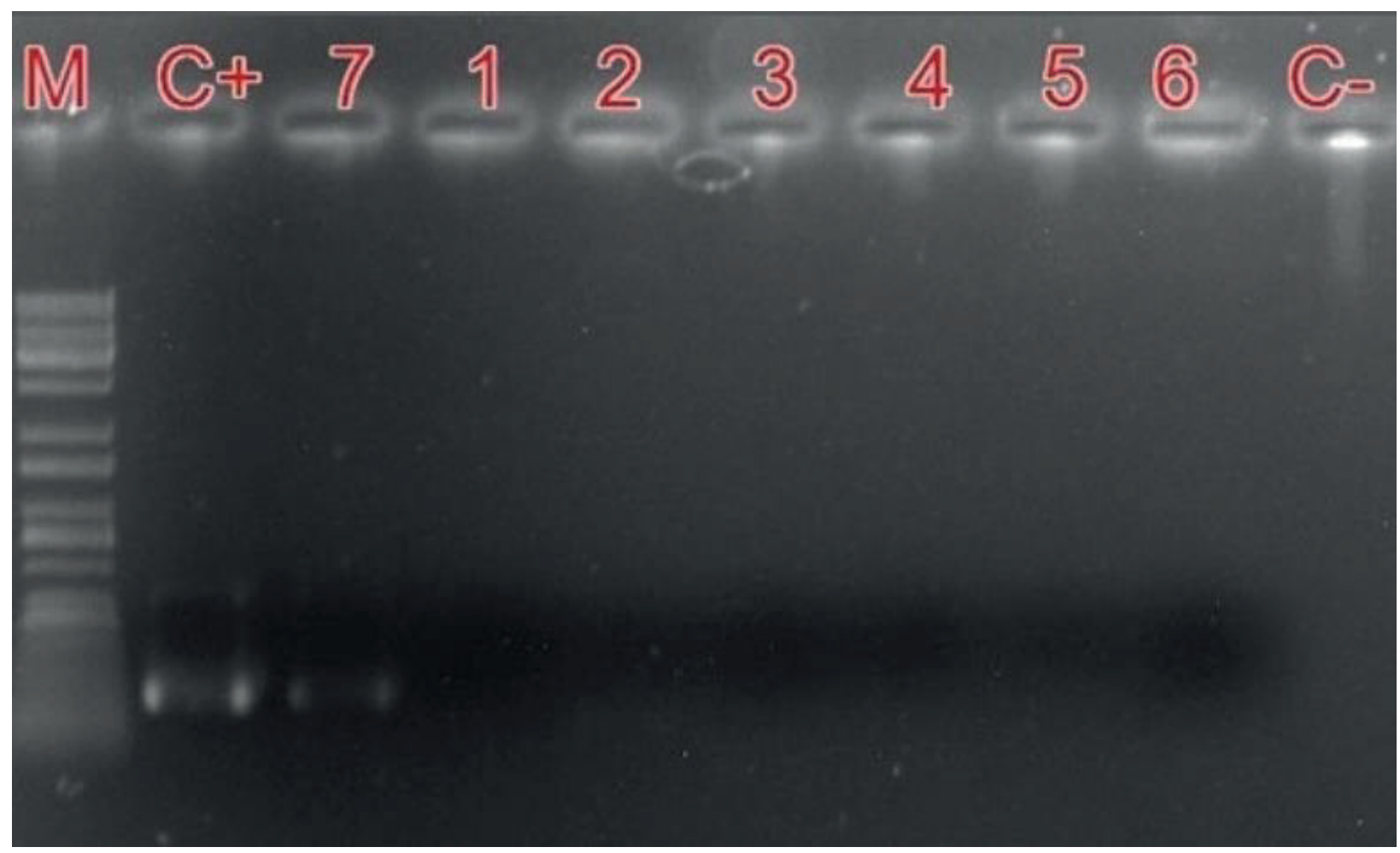

Figure 1. Nested-PCR results, shown on a 2\% agarose for Leptospira spp. from free-living capybara (Hydrochaeris hydrochaeris) serum samples from a university campus in the city of Araras in São Paulo, Brazil, 2013-2014. 1 molecular marker (100 bp) (Invitrogen ${ }^{\circledR}$, Brazil); $2 \mathrm{C}+$, positive control; 7 sample with DNA amplification (331 pb); $1,2,3,4,5$ and 6 tested samples; C-, negative control. 


\section{Discussion}

Considering the synanthropic process that has been affecting the capybaras due to changes in their natural habitat, and the shortening of the distance between that animal species and humans, research has been developed for the purpose of verifying the presence of anti-Leptospira spp. antibodies and the results varied according to the different study sites (Silva et al., 2009; Cueva et al., 2010; Chiacchio et al., 2014).

The MAT data for the presence of anti-Leptospira spp. antibodies in $93.55 \%$ of the capybaras are higher than those found in the state of São Paulo by Chiacchio et al. (2014) that collected blood from 31 capybaras from the Alberto Löfgren State Park in the city of São Paulo and detected anti-Leptospira spp. antibodies by MAT in $26 \%$ of the animals. In addition, these values are higher than those found by Shimabukuro (2006) when studying the capybaras of the Alto Tietê basin and the metropolitan region of São Paulo, which were $3.60 \%$ and $35 \%$, respectively, by MAT. Furthermore, results from other studies using MAT assay indicate that antiLeptospira spp. antibodies were found in fewer capybaras as compared to the findings of our study. Lopez (2010) detected anti-Leptospira spp. antibodies in $27 \%$ of the studied animals, from the states of São Paulo (SP), Paraná, Rio de Janeiro, and Minas Gerais, and the study conducted by Cueva et al. (2010) that detected $86 \%$ of reagent samples in capybara of the Iquitos Zoo, Peru.

The serological results of this study may have been influenced by differences in the prevalence of animal leptospirosis in the corresponding study locations, as well as reflecting the study period, which may have provided greater or lower probabilities of the infection occurring in the animals (Dreer et al., 2013). In this study, the high prevalence of the leptospira infection may also be attributed to the fact that capybaras live in damp and muddy locations, which provides higher survival of the etiologic agent (Faine et al., 1999).
Regarding the antibodies against serovars detected in this study, Grippotyphosa (69.23\%) presented the highest prevalence, followed by Autumnalis (26.92\%) and Bratislava (3.85\%). A similar result was also reported by Lopez (2010) with a higher prevalence $(14.49 \%)$ to the Grippotyphosa serovar. However, these results do not corroborate with those reported by Chiacchio et al. (2014), where the most prevalent serovars were Canicola, Tarassovi and Hardjo, with 12.9\% each.

The different antibodies against the serovars detected in the aforementioned studies may be related to the host animals that co-inhabited with the capybaras in each study location, and the knowledge of the serological variant is essential for the characterization of the local epidemiology. The serological variant may not present host specificity but host preference, which may indicate a probable reservoir species in the location of the infection (Faine et al., 1999), thus allowing preventive measures to be taken in order to control the infection.

It is important to emphasize that the occurrence of accidental infections caused by serovars that are not kept in this species suggests that the transmission of leptospirosis may take place through direct exposure of the animals to environments that have been contaminated by other animals, whether domestic or wild (Coelho et al., 2014).

This study detected Leptospira spp. DNA in one serum sample, a lower value than that detected by Paixão in 2013, where the DNA was detected in 38\% of blood samples analyzed from different species of wild animals, with rodents among them. The results of both studies confirm the presence of the bacteria in the bloodstream in the initial phase of the disease. After the animal is infected with Leptospira spp., bacteria are excreted in the urine for different periods (Faine et al., 1999; Oliveira et al., 2013). In addition, the molecular results of our work suggest the possibility of dissemination of etiological agent by these rodents. Further, studies by Marvulo et al. (2009) confirmed the intermittent elimination of the 
bacterium in the urine between days 9 and 43 after infection in experimentally infected capybaras. Other studies carried out in Brazil, with serology and agent isolation, suggest the role of capybaras in the maintenance and transmission of Leptospira spp. (Ito et al., 1998; Marvulo et al., 2002; Pimentel et al., 2009).

\section{Conclusion}

The free-living capybaras can be used as a bioindicator of leptospiral infection in the study region. In addition, this study provided evidence for the presence of DNA and anti-Leptospira spp. antibodies in free-living capybara. Thus, characterization of these animals as possible carriers and disseminators of the etiological agent in the environment allows the identification of the infection in other animals and campus visitors. Considering that the habitat of these animals is the lakes within a university campus, it is necessary to inform the concerned population to avoid the use of the respective water bodies for any activity, investigate the real source of infection of these animals, and apply adequate measures for the prevention of disease.

\section{Acknowledgments}

The authors would like to thank the UNIPAR and PROEX from the Federal University of São Carlos (UFSCar) for the financial support granted to this study, and CAPES for granting of the PROSUP school fee.

\section{References}

Almeida, L. P. D., Martins, L. F. D. S., Brod, C. S., \& Germano, P. M. L. (1994). Serological survey of leptospirosis among environmental sanitation workers in an urban locality in Southern Brazil. Revista de Saúde Pública, 28(1), 76-81. doi: 10.1590/ S0034-89101994000100009
Antonucci, A. M., Souza, G. T., Ribeiro, T. S., Takemoto, R. M., \& Pavanelli, G. C. (2012). Infestação de Protozoophaga obesa e Strongyloides sp. em capivaras, Hydrochaeris hydrochaeris, de vida livre da planície de inundação do alto rio Paraná, Brasil. Anais do III Congresso Internacional de Parasitologia Neotropical (p. 39). Lima, Peru: The Biologist.

Carneiro, B. F., Miranda, M. M. D., Silveira, O. J. D., Neto, Linhares, G. F. C., \& Araújo, L. B. D. M. (2014). Inquérito sorológico para toxoplasma gondii em mamíferos neotropicais mantidosno centro de triagem de animais silvestres, Goiânia, Goiás. Revista de Patologia Tropical, 43(1), 69-78.

Chiacchio, R. G. D., Prioste, F. E. S., Vanstreels, R. E. T., Knöbl, T., Kolber, M., Miyashiro, S. I., \& Matushima, E. R. (2014). Health evaluation and survey of zoonotic pathogens in free-ranging capybaras (Hydrochoerus hydrochaeris). Journal of Wildlife Diseases, 50(3), 496-504. doi: 10.7589/2013-05-109

Coelho, É. L. M., Chaves, N. P., Sá, J. C. de, Melo, S. de A., \& Silva, A. L. A. (2014). Prevalência de leptospirose em fêmeas bovinas abatidas em frigoríficos no município de São Luís, MA. Brazilian Journal of Veterinary Medicine, 36(2), 111-115.

Cueva, A., Rivera, G., Sánchez, P., \& Ramírez, V. (2010). Incidence of infection for Leptospira spp. in capybaras (Hydrochoerus hydrochaeris) reared in captivity in iquitos. Revista de Investigaciones Veterinarias del Perú (RIVEP), 21(1), 106-112.

Dreer, M. K. P., Gonçalves, D. D., Caetano, I. C. da S., Gerônimo, E., Menegas, P. H., Bergo, D.,... Martins, L. A. (2013). Toxoplasmosis, leptospirosis and brucellosis in stray dogs housed at the shelter in Umuarama municipality, Paraná, Brazil. Journal of Venomous Animals and Toxins Including Tropical Diseases, 19(23), 1-5. doi: 10.1186/1678-9199-1923

Faine, S., Adler, B., Bolin, C., \& Perolat, P. (1999). Leptospira and Leptospirosis (2a ed.). Melbourne: MedSci.

Gonçalves, D. D., Teles, P. S., Reis, C. R. D., Lopes, F. M. R., Freire, R. L., Navarro, I. T.,... Freitas, J. C. D. (2006). Seroepidemiology and occupational and environmental variables for leptospirosis, brucellosis and toxoplasmosis in slaughterhouse workers in the Paraná State, Brazil. Revista do Instituto de Medicina Tropical de São Paulo, 48(3), 135-140. doi: 10.1590/ S0036-46652006000300004 
Ito, T. A., Cacioppo, J. T., \& Lang, P. J. (1998). Eliciting affect using the International Affective Picture System: Trajectories through evaluative space. Personality and social psychology bulletin, 24(8), 855-879. doi: 10.1177\%2F0146167298248006

Lopez, R. P. G. (2009). Avaliação sanitária de animais silvestres de produção abatidos em abatedouro, Dissertação de mestrado, Faculdade de Medicina Veterinária e Zootecnia, Universidade de São Paulo, SP, Brasil.

Marvulo, M. F. V., Paula, C. D., Ferreira, P. M., Morais, Z. M., Delbem, A. C. B., Fávero, A. C. M.,... Vasconcellos, S. A. (2002). Detection of Leptospira in two free living populations of capybaras (Hydrochaeris hydrochaeris) from São Paulo State, Brazil. Bridgetown: International Leptospirosis Society.

Marvulo, M. F. V., Silva, J. C. R., Ferreira, P. M., Morais, Z. M. de, Moreno, A. M., Doto, D. S.,... Ferreira, J. S., Neto, (2009). Experimental leptospirosis in capybaras (Hydrochaeris hydrochaeris) infected with Leptospira interrogans serovar Pomona. Journal of Zoo and Wildlife Medicine, 40(4), 726730. doi: 10.1638/2007-0042.1

Merien, F., Amouriaux, P., Perolat, P., Baranton, G., \& Saint Girons, I. (1992). Polymerase chain reaction for detection of Leptospira spp. in clinical samples. Journal of Clinical Microbiology, 30(9), 2219-2224.

Myers, D. M. (1985). Manual de Metodes para el diagnostico de la leptospirose. Buenos Aires: Centro Panamericano de Zoonoses. Nota Tecnica, 30.

Oliveira, S. V., Arsky, M. D. L. N. S., \& Caldas, E. P. (2013). Reservatórios animais da leptospirose: Uma revisão bibliográfica. Saúde, 39(1), 9-20. doi: $10.5902 / 223658345094$

Pacheco, F. C., Moraes, J., F $\mathrm{F}^{\circ}$, Rocha, V. J., Sampieri, B. R., Zaniolo, M. M., Pachaly, J. R.,... Dib Gonçalves, D. (2017). Anti-Rickettsia rickettsii antibodies in capybaras (Hydrochoerus hydrochaeris Linnaeus, 1766) from an agricultural landscape in Araras, São Paulo, Brazil. Semina: Ciências Agrárias, 38(4), 2543-2550. doi: 10.5433/1679-0359.2017v38n4Supl1p2543

Pimentel, J. S., Gennari, S. M., Dubey, J. P., Marvulo, M. F., Vasconcellos, S. A., Morais, Z. M.,... Evêncio Neto, J. (2009). Inquérito sorológico para toxoplasmose e leptospirose em mamíferos selvagens neotropicais do Zoológico de Aracaju, Sergipe. Pesquisa Veterinária Brasileira, 29(12), 1009-1014. doi: 10.1590/S0100736X2009001200010
Rodrigues, M. V. (2013). Aspectos ecológicos e controle reprodutivo em uma população de capivaras sinantrópicas no campus da Universidade Federal de Viçosa-Viçosa, MG. Tese de doutorado, Medicina Veterinária, Universidade Federal de Viçosa, Viçosa, MG, Brasil.

Rodrigues, M. V., Paula, T. A. R., Ferreira, L. B. C., Ávila, E. C., Silva, L. C., \& Souza, V. B. (2013). Comportamento de um grupo de capivaras em uma área urbanizada. Acta Veterinaria Brasilica, 7(3), 212-217. doi: 10.21708/avb.2013.7.3.3142

Santos,R.F.D.(2017).Caracterizaçãosoroepidemiológica da infecção por Leptospira spp. em rebanhos bovinos de corte do Estado de Mato Grosso do Sul, Brasil. Tese de doutorado, Medicina Veterinária, Faculdade de Ciências Agrárias e Veterinárias, Universidade Estadual Paulista, Câmpus de Jaboticabal, SP, Brasil.

Santos, F. G. A., Zamora, L. M., \& Ribeiro, V. M. F. (2011). Controle de parasitas intestinais de capivaras (Hydrochaerus hydrachaeris) criadas em sistema semi-extensivo, no município de Senador Guimard Santos, Acre. Acta Veterinaria Brasilica, 5(4), 393398. doi: 10.21708/avb.2011.5.4.2637

Shimabukuro, J. S. (2006). Estudo da Soroprevalência de Leptospira spp. em capivaras (Hydrochaeris Hydrochaeris) na bacia hidrográfica do Alto Tietê, $S P$. Dissertação de mestrado, Universidade de São Paulo, São Paulo, SP, Brasil.

Silva, É. F., Seyffert, N., Jouglard, S. D., Athanazio, D. A., Dellagostin, O. A., \& Brod, C. S. (2009). Soroprevalência da infecçao leptospiral em capivaras (Hydrochoerus hydrochaeris) abatidas em um frigorífico do Rio Grande do Sul. Pesquisa Veterinária Brasileira, 29(2), 174-176.

Sinkoc, A. L., Brum, F. A., Muller, G., \& Brum, J. G. W. (2004). Helmintos parasitos de capivara (Hydrochoerus hydrochaeris L. 1766) na região de Araçatuba, São Paulo, Brasil. Arquivos do Instituto Biológico, 71(3), 329-333.

Vasconcellos, S. A., Ito, F. H., \& Cortes, J. A. (1987). Bases para a prevenção da brucelose animal. Comunicações Cientificas da Faculdade de Medicina Veterinária e Zootecnia da Universidade de São Paulo, 11(1), 25-36.

Paixão, M. S. (2013). Diagnóstico laboratorial da infecção por Leptospira spp. em animais silvestres e em roedores procedentes do centro de conservação da fauna silvestre de Ilha Solteira-SP. Dissertação de mestrado, Faculdade de Medicina, Programa de Pós-Graduação em Doenças Tropicais, Universidade Estadual Paulista, Campus de Botucatu, SP, Brasil. 